Transnational Play 



\section{Transnational Play}

Piracy, Urban Art, and Mobile Games

Anne-Marie Schleiner

Amsterdam University Press 
Cover illustration: Don Gravity (2011) by Nightspade Studio, Bandung, Indonesia; Game Screenshot.

Cover design: Coördesign, Leiden

Lay-out: Crius Group, Hulshout

$\begin{array}{ll}\text { ISBN } & 9789463728904 \\ \text { e-ISBN } & 9789048543946 \\ \text { DOI } & 10.5117 / 9789463728904 \\ \text { NUR } & 670\end{array}$

(c) A.-M. Schleiner / Amsterdam University Press B.V., Amsterdam 2020

All rights reserved. Without limiting the rights under copyright reserved above, no part of this book may be reproduced, stored in or introduced into a retrieval system, or transmitted, in any form or by any means (electronic, mechanical, photocopying, recording or otherwise) without the written permission of both the copyright owner and the author of the book.

Every effort has been made to obtain permission to use all copyrighted illustrations reproduced in this book. Nonetheless, whosoever believes to have rights to this material is advised to contact the publisher. 